\title{
Research
}

\section{Total Environment of Change: Impacts of Climate Change and Social Transitions on Subsistence Fisheries in Northwest Alaska}

\author{
Katie J. Moerlein ${ }^{1}$ and $\underline{\text { Courtney Carothers }}^{1}$
}

\begin{abstract}
Arctic ecosystems are undergoing rapid changes as a result of global climate change, with significant implications for the livelihoods of Arctic peoples. In this paper, based on ethnographic research conducted with the Iñupiaq communities of Noatak and Selawik in northwestern Alaska, we detail prominent environmental changes observed over the past twenty to thirty years and their impacts on subsistence-based lifestyles. However, we suggest that it is ultimately insufficient to try to understand how Arctic communities are experiencing and responding to climate change in isolation from other stressors. During interviews and participant observation documenting local observations of climatic and related environmental shifts and impacts to subsistence fishing practices, we find the inseparability of environmental, social, economic, cultural, and political realms for community residents. Many of our informants, who live in a mixed economy based on various forms of income and widespread subsistence harvesting of fish and game, perceive and experience climate change as embedded among numerous other factors affecting subsistence patterns and practices. Changing lifestyles, decreasing interest by younger generations in pursuing subsistence livelihoods, and economic challenges are greatly affecting contemporary subsistence patterns and practices in rural Alaska. Observations of climate change are perceived, experienced, and articulated to researchers through a broader lens of these linked lifestyle and cultural shifts. Therefore, we argue that to properly assess and understand the impacts of climate change on the subsistence practices in Arctic communities, we must also consider the total environment of change that is dramatically shaping the relationship between people, communities, and their surrounding environments.
\end{abstract}

Key Words: Arctic; climate change; environmental anthropology; fisheries; human dimensions; local knowledge; socialecological systems; subsistence; traditional ecological knowledge

\section{INTRODUCTION}

Although the political dimensions of global climate change continue to produce debate, a scientific consensus has emerged that global temperatures are increasing with particularly dramatic changes occurring in Arctic ecosystems (ACIA 2005, Ford and Furgal 2009). Arctic average temperature has risen by $2-3^{\circ} \mathrm{C}$, almost twice the rate of increase in lower latitudes over the past several decades (Corell 2006). The global phenomenon of climate change and the regional intensity of change in the Arctic are experienced at local scales. There is a recognition among Arctic residents that the regional climate has changed within living memory (Krupnik and Jolly 2002). Recently, more attention has been given to documenting local observations of climate change to provide a richer understanding of the complexities of ecosystem processes (Moller et al. 2004) and to understand the vulnerability of social-ecological systems to impacts of climate change (Ford et al. 2006).

A growing number of studies have attempted to understand indigenous knowledge and perceptions of climate change, primarily in regions expected to experience the most pronounced changes (Riedlinger and Berkes 2001, Nichols et al. 2004, Hinzman et al. 2005, Berkes 2008). This flurry of research is in part due to a growing recognition within scientific disciplines that indigenous communities possess a deep and holistic understanding of complex systems based on long-term interactions with their surroundings (Berkes et al. 2000, Dowsley 2009). In addition to recent interest in indigenous knowledge of environmental change, many studies have sought to understand the vulnerability of indigenous communities to changing weather, travel, and hunting conditions (Hinzman et al. 2005, Ford et al. 2008, Ford 2009). Some argue that changing climatic conditions present formidable challenges to human health and food security, and "possibly even the survival of some cultures" (Corell 2006:151). The widespread circulation of this discourse of vulnerability has created a fertile context for research that focuses on the social, cultural, and economic impacts of climate change in the Arctic, the "bellwether for the global implications of climate change" (Corell 2006:149).

Although many researchers document the observations and experiences of indigenous communities as they relate to climate change (Krupnik and Jolly 2002), it becomes ever more apparent that there are numerous additional and perhaps more pressing changes facing Arctic communities (Fox 2002). Research suggests that the Arctic region, specifically indigenous communities, have historically faced, and continue to face dramatic political, social, cultural, and economic changes (Ford and Smit 2004, West and Hovelsrud 2010). Increasingly, scholars situate climate change amongst a myriad of social and natural transformations that influence how communities are affected by climate change (Turner et 
al. 2003, Tyler et al. 2007). The Arctic's indigenous populations are not inexperienced in dealing with climategenerated stress (Cruikshank 2001, Burch 2006). In the recent past, social shifts have posed much more serious challenges to subsistence cultures. Within living memory, populations in the Arctic have become sedentary, traditional land-based activities have declined, industrialization and consumerism have been introduced, and ownership and management of much of the region's land and natural resources have been usurped by outside bureaucratic bodies (Duerden 2004).

In this paper, based on the unexpected results of our ethnographic research conducted in the Iñupiaq communities of Noatak and Selawik in northwestern Alaska, we suggest that it is ultimately insufficient to try to understand how Arctic communities are experiencing and responding to climate change in isolation from other stressors. During interviews and participant observation documenting local observations of climatic and related environmental shifts and impacts to subsistence fishing practices, we observed the inseparability of environmental, social, economic, cultural, and political realms for community residents. Many of our informants, who live in a mixed economy based on income from wage work, small businesses, corporate dividends, and/or transfer payments, and widespread subsistence harvesting of fish and game, perceive and experience climate change as embedded among numerous other factors affecting subsistence patterns and practices. Changing lifestyles, decreasing interest by younger generations in pursuing subsistence livelihoods, and economic challenges are dramatically reshaping subsistence patterns and practices in rural Alaska. As our research demonstrates, observations of climate change are perceived, experienced, and articulated to researchers through a broader lens of these linked lifestyle and cultural shifts. Therefore, we argue that to properly assess and understand the impacts of climate change on the subsistence practices in Arctic communities, we must also consider the "changing total environment" (C. Garcia-Quijano, J. Poggie, and A. Pitchon, unpublished manuscript) that is dramatically shaping the relationship between people, communities, and their surrounding environment.

Several researchers have also recognized this key point and have presented integrated models for assessing change across social-ecological domains. Researchers in Barrow, Alaska, for example, demonstrate that the confluence of interacting human and natural factors together shape the vulnerability of the community to climate change (Lynch and Brunner 2007). Loring and Gerlach (2009) argue that an understanding of food security in rural Alaska requires an integrated assessment of linked socio-cultural, ecological, psychological, and biomedical aspects of individual and community health. These two examples explore the concepts of vulnerability and food security, notions that make central the linkages of the social to the ecological. In our case, however, we found a more fundamental inseparability of social-ecological domains. Even in our attempts to limit our discussion to observations of environmental change, informants consistently discussed wide-ranging shifts in ecological, social, cultural, political, and economic realms as they are experienced together. Our study that started as a study of climatic and related ecological shifts necessarily grew to explore the total environment of change that our informants detailed in their holistic responses.

\section{METHODS}

This study draws upon ethnographic research conducted in 2010 and 2011 in the Iñupiaq communities of Noatak and Selawik, including semistructured interviews with 38 key informants and detailed participant observation. With assistance from community leaders, we selected a purposive sample of key informants based on age, long-term residency in the region, long-term participation in fishing activities, availability, and willingness to participate in the project. Our interviews were open-ended and semidirected to enable flexibility of responses (Huntington 1998). We directed informants to discuss environmental changes in the dominant seasons, i.e., open water season and ice season, their knowledge about the distribution and abundance of targeted subsistence fish, observations of species-level changes, and weather and seasonal patterns that affect traditional harvesting and processing techniques and schedules. Although unprompted, we encouraged our informants to discuss other challenges and topics of importance to their subsistence activities. We analyzed verbatim interview transcripts and field notes with inductive thematic coding in Atlas.ti (Bernard 2002).

In addition to interviews, we used participant observation to provide more in-depth information about subsistence fishing activities in Noatak and Selawik and to establish and maintain relationships with active and experienced fishers in the communities (Jorgensen 1989, Bernard 2002). We traveled by boat with local families throughout the local river systems, stayed at fishing and hunting camps, harvested and processed fish and game alongside local experts, participated in the dayto-day activities in the communities, and attended social functions, such as church gatherings and community cleanups. We visited the communities primarily during the summer months, the most active season for fishing, but also made trips to both communities during the fall and winter seasons. The duration of our community visits ranged between three days to three weeks. Our trips to fish camps ranged from singleday to week-long stays. Over the course of our study, we reported to tribal and local governments and held community meetings to share our findings, discuss future directions of the project, and gain feedback from community members about the accuracy of our results. 


\section{BACKGROUND}

The contemporary community of Noatak is located about 120 $\mathrm{km}$ upstream from the mouth of the Noatak River and is about $90 \mathrm{~km}$ north of Kotzebue, the regional hub of the Northwest Arctic Borough. The population of Noatak is about 514 (U.S. Census Bureau 2010). The contemporary community of Selawik is located at the mouth of the Selawik River, about $112 \mathrm{~km}$ southeast of Kotzebue (Fig. 1). Selawik has a population of 829 people, making it the second largest community in the region (U.S. Census Bureau 2010). Over $90 \%$ of residents of both communities identify as Iñupiaq Eskimo. Before the 1900s, the Iñupiat of this region lived a primarily nomadic lifestyle, following a seasonal movement pattern that closely corresponded to the availability of food sources. People focused efforts on harvesting caribou (Rangifer tarandus), sea mammals, salmon, and other fish species (Burch 2006). The arrival of American whaling ships to the region instigated a wave of sustained social changes, including the establishment of missionary schools and health services in the 1890s (Chance 1990). The Friends Quaker Church erected federally supported schools along the Noatak and Selawik rivers in 1907 and 1908. As a result, the previously nomadic and dispersed Iñupiat built permanent homes near the schools, creating villages that still remain (Drucker 1996).

Fig. 1. Research area: Selawik and Noatak in northwest Alaska. Image created by Nicole Braem.

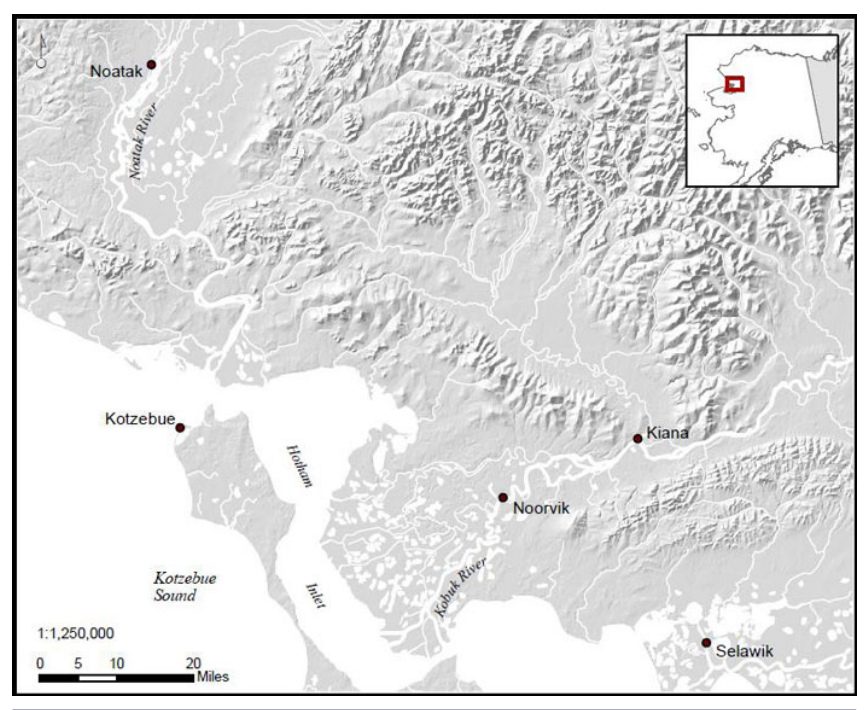

Within the past 50 years, pronounced social, cultural, economic, and political changes have continued to shape contemporary ways of life in northwest Alaska villages. In the 1960s, snow machines replaced sled dog travel, dramatically decreasing local needs for fish and increasing reliance on fossil fuels (Hall 1971). In 1971, the Alaska Native Claims Settlement Act extinguished aboriginal claims to land and resources by transferring title and monetary compensation to newly established indigenous corporations, forever changing tribal resource rights and governance across the state (Case and Voluck 2002). The conditions of the communities continue to change rapidly, with increasing amounts of infrastructure developed each year.

Such developments have had dramatic impacts on the lifestyle, culture, and subsistence practices of residents in Noatak and Selawik. Acculturation is closely associated with decreasing well-being and high levels of psychosocial stress among Alaska Natives (Wolsko et al. 2006, Wolsko et al. 2007). A nutritional transition is occurring in indigenous communities throughout the Arctic, with severe implications for physical, as well as psychosocial health (Kuhnlein et al. 2004). Local and traditional food is at the heart of culture and health, yet younger generations of Alaska Natives increasingly consume store-bought food (Bersamin et al. 2006). The high degree of government intervention and lacking economic opportunities in rural Alaska continue to undermine local self-determination and sustainability (Napoleon 1996). Throughout rural Alaska, these and other linked challenges persistently reshape local human-environment relations, community identity, and subsistence economies.

Despite the socioeconomic and cultural changes that have occurred over the past century in northwest Alaska, residents of Noatak and Selawik do continue to embrace a way of life orientated toward harvesting local resources. Residents of these communities on average harvest and consume approximately $165 \mathrm{~kg}$ of wild foods per person per year (Magdanz et al. 2010). These communities can be characterized as mixed economies, in which a pattern of subsistence production based on hunting, fishing, and gathering is supported by varying levels of engagement in wage labor and transfer payments and coexists within a market-based economy for goods and services (Wolfe and Ellanna 1983, Wolfe and Walker 1987, Buklis 1999). Transportation to and from Noatak and Selawik is limited to air and water. In addition to providing a nearly continuous supply of fish, the Noatak and Selawik rivers serve as vital transportation thoroughfares, connecting a network of communities. Local travel occurs by small boat, snow machine, and all-terrain vehicle.

In Noatak, caribou, marine mammals, berries, and fish make up the majority of wild food harvests (Magdanz et al. 2010). Fish are often the most reliable subsistence resource in Noatak and Selawik. In Noatak, chum salmon (Oncorhynchus keta; Iñupiaq: aqalugruaq), Dolly Varden (Salvelinus malma; agalukpiq, locally called trout) and several species of whitefish (Coregonus sp.; qalupiaq) make up the majority of the catch. After ice break-up in the spring, many residents of Noatak travel to coastal camps to harvest bearded seal (Erignathus barbatus; ugruk), beluga (Delphinapterus leucas; sisuaq), and several species of whitefish. Residents return to Noatak by July, to begin setting gillnets for migrating chum salmon. 
Table 1. Common observations of a total environment of change as described by informants of Noatak and Selawik.

\begin{tabular}{|c|c|}
\hline Salient Themes & Common Observations \\
\hline \multirow[t]{6}{*}{ Physical environmental change } & Less snow in winter \\
\hline & Shallower river water \\
\hline & High river water events are less common \\
\hline & Melting permafrost increases erosion and drying \\
\hline & Later fall freeze-up; new freeze-thaw cycle \\
\hline & Earlier spring break-up; ice now melts in place \\
\hline \multirow[t]{4}{*}{ Changes in fish distribution and abundance } & Less predictable fish movement timing \\
\hline & Increased presence of beaver affects fish \\
\hline & Less whitefish, more pike observed in Selawik \\
\hline & Less Dolly Varden observed in Noatak \\
\hline \multirow[t]{4}{*}{ Travel and access to resources } & Unpredictable ice conditions hinder winter travel \\
\hline & Lower river and lake levels make boating difficult \\
\hline & Less predictable fish timing challenges harvesting practices \\
\hline & Warmer springs cause unfavorable fishing conditions \\
\hline \multirow[t]{2}{*}{ Unpredictable fish processing weather } & Warmer, wetter weather causes traditionally dried fish to spoil \\
\hline & $\begin{array}{l}\text { New freeze-thaw cycles during fall challenges traditional fermentation and preservation } \\
\text { methods }\end{array}$ \\
\hline \multirow[t]{6}{*}{ Socioeconomic and cultural change } & Rapidly changing living conditions \\
\hline & Technological developments alter subsistence needs and activities \\
\hline & Increasing cost of subsistence equipment limits participation \\
\hline & High gasoline prices limit access to fishing and hunting locations \\
\hline & Declining participation of youth in subsistence activities \\
\hline & Eating more store food and less local food \\
\hline
\end{tabular}

Shortly before the river freezes, people begin seining for Dolly Varden and whitefish. During the winter, people opportunistically fish for Dolly Varden with rod and reel through the ice. In Selawik, local harvesters devote much of their effort to catching several species of whitefish, sheefish (Stendous leucichthys; sii), and northern pike (Esox lucius; siilik). Spring fishing in Selawik begins once the weather warms and the days lengthen. People use rod and reel to fish for sheefish in the larger lakes surrounding Selawik. After ice break-up occurs and water levels drop, families travel to their fish camps to set gillnets for whitefish and pike. After a couple of weeks, the water becomes too warm and fish spoil if left in the net for even a short period of time. During fall, the same fish are targeted in the same manner as in the spring. Selawik residents also participate in under ice fishing for whitefish with gillnets early in winter before the ice becomes prohibitively thick. During fall, Selawik and Noatak residents also hunt for moose (Alces alces) and caribou. Arctic grayling (Thymallus arcticus; suluqpaugaq), burbot (Lota lota; tiktaaliq), and several other species of fish are targeted to a lesser degree in both communities. Fishing and hunting practices in both communities are extremely flexible and dynamic as people respond to ever changing conditions and resource needs.

\section{OBSERVATIONS OF A TOTAL ENVIRONMENT OF CHANGE}

The observations of Noatak and Selawik elders and active resource harvesters consistently provided tangible evidence of climate change during our interviews and observations. Based on our inductive coding of interview data, we observed four salient themes of climate change observations and impacts on subsistence practices: physical environmental change, changes in fish distribution and abundance, travel and access to resources, and unpredictable fish processing weather. The environmental changes observed over the past 20 to 30 years are described by informants as being without precedent and outside of the normal range of variation. The observations indicated increasing variability in weather conditions and increasingly unpredictable fish distributions, which have significant implications for subsistence activities. These phenomena are not unique to northwest Alaska. Communities in the Canadian Arctic and Alaska have been reporting similar environmental changes (Berkes and Jolly 2001, Riedlinger and Berkes 2001, Krupnik and Jolly 2002, Oozeva et al. 2004). A fifth theme also emerged from our data. The four environmental themes were discussed in the context of socioeconomic and cultural changes that have affected how subsistence livelihoods are pursued today. Following our informants' framing of these social dimensions as inseparable from the environmental, we include them, drawing attention to the total environment of change occurring in Arctic Alaska (Table 1).

\section{Physical environmental change}

Informants from both communities consistently noted many changes in the physical environment related to changing 
climatic conditions, specifically changing river conditions. Informants perceived the nature and timing of river break-up to be different now than in the past. Several informants in Selawik noted that the ice now usually melts very quickly observing that the ice does not "break up anymore, it just melts in place." Similarly, Noatak informants consistently noted that there are no longer any "big break-ups; the ice just melts out." Several informants noted a trend of river break-up occurring earlier compared with past decades, although other informants noted that the timing of break-up has remained about the same. High water events associated with spring break-up are widely perceived to be less severe than in the past. Informants in both communities mention that the timing of freeze-up is less predictable. Most informants noted that freeze-up tends to occur later now than in the past and that a new freeze-thaw cycle now characterizes the freeze-up period. Thawing permafrost and increased erosion along the river edges are being observed in both communities. Informants related melting permafrost to sinking ground and the draining of lakes. The largest thaw slump documented in North America, measuring $220 \mathrm{~m} \times 200 \mathrm{~m} \times 25 \mathrm{~m}$ deep, occurred along the Selawik River in 2004 (Crosby 2009).

\section{Changes in fish distribution and abundance}

Informants linked the observed changes in the conditions of the waterways and weather with changing fish distribution and abundance. In Noatak, elders noted that Dolly Varden, the most important subsistence fish resource for the community, are less numerous and the size distribution has changed. Informants attributed this change to several factors including: increasing beaver activity, shallower river levels, warmer water temperatures in the summer that create unfavorable spawning conditions, and melting permafrost that leads to increased sedimentation in the spawning beds of the Dolly Varden, which decreases egg survival. In Selawik, informants noted that they are catching fewer broad and humpback whitefish (Coregonus nasus and C. pidschian, respectively) and more pike than in the past. Informants attributed the decline in whitefish to several factors. Some noted that pike feed on whitefish and increasing pike abundance may be related to a decline in whitefish abundance. Others related the decline in whitefish to beaver activity. Over the past couple of decades, beaver abundance has increased. Beaver dams block waterways, which limits the movement of whitefish between spawning, feeding, and overwintering grounds.

\section{Travel and access to resources}

Changing water levels, fish movement patterns, and weather conditions all create challenges for local harvesters to meet their subsistence needs. Residents from both communities noted that the river levels are lower on average during the open water season, partly because of changing precipitation patterns. This change affects transportation and access to important fishing locations. Boats commonly become stuck on the bottom or hit rocks while traveling, often causing prohibitively expensive damage to the lower units of engines. Families travel to fish camps during the spring and fall to pursue several species of whitefish, Dolly Varden, and pike as they undergo seasonal migrations. Residents now struggle to determine when to travel to their fish camps to catch the fish runs. Several experienced fishermen described how they missed the bulk of the fish moving by their camp in the recent past, arriving either too early or, more commonly, after the fish had already passed. Faster spring break-up limits the amount of time available for spring ice fishing, which provides a desirable source of fresh protein after the long winter. Increasingly warmer weather during spring greatly impedes the harvest of quality fish, because of warmer water conditions. A Selawik resident described how warm water affects fishing: "The water's too warm. You'd like to stay at camp, like, another couple weeks, but the sun is too hot. You have to pull out your net because the fish get too soft before you're even done trying to scale them and cut them. They're just no good." Later and longer ice freeze-up affects access to resources and travel. Increasingly frequent freeze-thaw cycles in the fall make it difficult to decide when to store boats and rely solely on snow machines for travel.

Unpredictable weather affects traditional fish processing The Iñupiat of northwest Alaska have developed a complex body of knowledge regarding processing fish in the Arctic environment. Traditional drying and aging methods do not require the use of electric freezers, but instead make use of cool fall and spring weather. Increasingly less predictable weather hinders traditional fish processing methods. Residents of both communities recounted to us instances of being forced to throw drying fish away that had rotted in unexpected rainy weather. As one Selawik elder notes:

Long time ago we don't really take care of our fish. When we hang them, they dry even though we never really take care of them. Springtime, fall time, September. [Now] you have to watch them from sun. Too hot. Our rains, even those are different. They're unpredictable. So we could count on it being dry when I was growing up in the springtime. And then the same thing in the fall time. Sometimes [now] it'd be so wet so much, people -- the fish can't dry nowadays.

As another informant noted, the recent occurrence of freezethaw cycles in the fall hinders the ability of people to produce "quaq," an important traditional dish of fermented, frozen fish:

I store away, like about, like two gunny sacks of quasriluk or broad fish whitefish, and it froze in October, and then it thawed, and then it rained, and then it freeze. My fish were too stink. My dogs didn't even want to eat any of it and I didn't want to eat it either. So I learned from that. 
Informants explain that they have shifted from drying and aging their fish outside in the traditional manner to relying on freezers for fish preservation.

\section{Socioeconomic and cultural change}

Within the context of interviews and participant observation based on exploring climate change and subsistence fisheries, we heard much about the broader context of change in subsistence livelihoods in this region. During interviews and participant observation, we learned that village residents do not perceive the environmental changes described above separately from other social changes in local fishing practices, but instead possess a holistic view of local conditions and the interacting drivers of change. We find this consistent with the literature on indigenous knowledge systems, in which knowledge, practice, and belief are inextricably linked and the dichotomization of the natural and the social worlds that often characterizes western thought is absent (Berkes 2008). In each of our interviews about environmental change, we found demonstration that residents of Noatak and Selawik recognize a unity of environmental and social spheres. The following interview excerpt from an interview in Noatak begins to reveal the inseparability of environmental-social change and the perception of village residents that climate change is simply one of many changes that have and are affecting the community.

Interviewer: We're trying to learn about environmental change, and if there's any changes going on in Noatak with the weather, with how the seasons are happening, and how that may be affecting subsistence fishing.

Informant: Just the weather changed so the - I think the world is changing, that's why. The weather's changing. Getting hotter every year. No more snow. We all move down [to the lower 48] states. We used to have no snow machine them days. Just dog team. Every household used to have dog teams.

Swift, unprompted transitions between environmental and social drivers of change, in this case from changing weather conditions to emigration trends to changing modes of transportation, happened with great frequency during interviews and casual conversations. We provide an overview of the salient socioeconomic and cultural changes that emerged during our ethnographic research.

Many of our older informants discussed significant differences between contemporary living and the lifestyles of their youth. Over time, expensive modern technology has replaced traditional fishing and hunting techniques. For example, snow machines replaced sled dog teams as the predominant winter mode of transportation around 1975 (Magdanz et al. 2010). As a result, families no longer have to catch large numbers of fish to feed dog teams throughout the year and people can travel across the land much more quickly. One Noatak informant noted:

When we were growing up ... we have to get what
we get out of the land ... You don't grow up like we
do. You don't have to feed your dogs. All you do is
just park the snow machine or 4-wheeler outside the
house. Before, you know, you have to cook for your
dogs too, you know. Day in, day out. Busy all the
time. You have to go out and get your wood before
we start using oil stove.

Today, the rural subsistence economy is heavily dependent on cash for the purchase and maintenance of equipment such as boat engines, snow machines, ice augers, and fishing nets. These shifts have increased the monetary requirements to pursue subsistence activities.

Economic concerns dominated our discussions with informants about challenges to subsistence practices. All interviewees stated that they worry about the high cost of fuel and equipment. Many informants noted that the high cost of gasoline, which is double to triple the cost of gasoline available in urban areas in the state, prevents access to hunting and fishing places, and a lack of rural employment limits income opportunities. In response to the constraint of high gasoline prices, families pool their financial resources to travel to hunting and fishing camps together. In Selawik, informants explained that they have begun setting their nets near town rather than traveling to fish camp to conserve gasoline. The cost of equipment and maintenance was also mentioned frequently by informants in both communities as a barrier to subsistence activity. We found that many people interested in going fishing were unable because they could not afford parts needed to fix their boats.

In addition to the challenges associated with the high cost of subsistence activities, participation in the wage economy affects people's ability to spend time hunting and fishing. Many families shape their activities at fish camp in the spring and fall around work schedules. One informant pointed out that nowadays there are "everyday fishermen" who do not hold a regular wage-earning job, and there are "Saturday fishermen," who are only able to go fishing on their days off. It used to be that families traveled to important fishing and hunting locations for weeks to months at a time, but now people travel to distance locations on day trips or stay one night in camp. This is related to the advent of fast transportation equipment like snow machines and powerful outboards. Places that used to require more than a day's travel can be reached in a few hours.

Changing social and economic conditions in Noatak and Selawik have made it difficult for the youth to develop the comparable hunting and fishing skill set as previous generations. Informants noted a general disconnect between 
the younger generation and subsistence practices, a trend characteristic of many northern subsistence-based cultures (Condon et al. 1995). Elders from both communities noted that access to a much greater number of conveniences such as cell phones, fast transportation, plumbing in the house, and store foods has resulted in a declining interest on the part of the youth to harvest local resources. Many felt that the contemporary youth have not learned how to work hard and perform activities that were basic necessities for the previous generation such as chopping wood, hauling water, and feeding dogs. People now eat more food available from local stores, which causes increased separation between local residents and their environment. The impact of store-bought foods was described by one Selawik informant in this way: "[there is] less fishing activity because there's more access to different kinds of food; more heatables, microwaveables, and less interest in our Native food. Lot of children, new generation, I don't think they like our style of food because they grew up with those microwaveables." Additionally, the youth are increasingly pressured to seek training and employment outside of the rural village communities, which further limits the potential for them to develop the harvesting skills of their parents and grandparents.

\section{DISCUSSION}

Residents of Noatak and Selawik are aware of climatic changes and the impacts of these shifting environmental conditions on subsistence practices. Lower water levels hinder boating access to important fishing locations. Unpredictable weather conditions challenge traditional fish processing methods. Changing fish abundances and movement patterns undermines a body of knowledge about local ecological conditions that has developed over generations. These environmental changes are not observed alone, but are discussed in the context of accompanying social changes that have dramatically altered subsistence production and economies. The rate of social, economic, and political change in Arctic communities has had a profound influence upon the way in which communities and individuals interact with the environment (Condon et al. 1995). The increasing cost of participating in subsistence activities and dramatic changes in the social context of Arctic indigenous communities are causing a seeming decline in local fishing and hunting knowledge and level of participation in subsistence practices. Thus, these communities face a total environment of change, whereby environmental changes and broader socioeconomic challenges are jointly shifting and remaking humanenvironment relationships. Although there is prolific discussion on the potential threat of climate change on subsistence practices and community well-being, it is the dramatic social changes and economic challenges that are perceived by local residents to be the main long-term threat to subsistence activities. Understanding and anticipating the consequences of climate change requires knowledge about the interactions of climate change and other social and environmental stresses facing communities (Huntington et al. 2007, Forbes et al. 2009).

Our findings are consistent with others who discuss the importance of considering the linkages between climate change and socioeconomic conditions (Turner et al. 2003, Tyler et al. 2007). Some have argued that social systems face "double exposure," a term used to describe the concurrent impacts of climate change and forces of globalization (O'Brien and Leichenko 2000). Although our ethnographic data suggest that social and technological changes such as the mechanization of subsistence production have been more dramatic drivers of change in this case than shifting seasonal patterns, informants do not separate out environmental changes from other kinds of changes they have experienced over time. Environmental changes are perceived and experienced through subsistence practice. For example, we see the linkage of environmental, economic, and social factors in informants' discussions of lower water levels in the Noatak River. Lower water levels force fishermen to burn more gas because "river shortcuts" are unavailable; traveling in shallow water presents risks for damaging boats and engines; low income levels and exorbitantly high costs of shipping to rural villages often prevents repair or replacement of broken parts, limiting future fishing access. Similarly, seasonal and fish movement shifts demonstrate the linked social-ecological subsistence system experienced in Noatak and Selawik. Less predictable weather and fish movement timing, combined with increasing participation in the wage economy has narrowed the windows of opportunity for fish harvesting and processing.

In these examples, observations of climate change are not cognitively separated from economic and social changes, in terms of how they influence relationships between local communities and local environments. To properly assess and understand observations and impacts of climate change on the subsistence practices in Arctic communities, we must necessarily consider the total environment of change that is dramatically shaping the relationship between people, communities, and their surrounding environment.

\section{CONCLUSIONS}

Given the increasing prevalence of climate change research and its predicted devastating impacts, we find it especially important to put climate change in context, as our informants have done, as one driver of change among a suite of stressors currently being experienced as a total environment of change in Arctic Alaska. Locally situated ethnographic research in Selawik and Noatak lends insight into the complex interactions between perceptible climatic changes and broad social, economic, cultural, and political changes and the combined impacts of these changes on subsistence economies in Arctic Alaska. Our ethnographic findings demonstrate that the 
dramatic socioeconomic and cultural transitions taking place in communities in northwest Alaska currently take precedence over climate change in terms of impacting the sustainability of subsistence practices and subsistence-based remote villages. However, we must also pay attention to the interaction of various impacts, such as the compounding nature of environmental and social change that dramatically affects the younger generations' ability to continue subsistence livelihoods. As others have argued, we find that the coupled human-environment system is too complex to draw neat conclusions about the implications of climate change (Gearheard et al. 2006); much ambiguity remains. Within a science-based way of knowing, ethnographic approaches that engage local perceptions of change are necessary to generate meaningful understandings of total environments of change and to inform effective strategies of response. The increasing focus on, and support for, climate change research provides an opportunistic lens for deeper explorations of linked environmental-social change. In this research on climate change, we have found it most appropriate to turn our attention to the total environment of change affecting subsistence practices and culture in Arctic communities to gain a better sense of how global phenomena are driving change in place and context.

Responses to this article can be read online at: http://www.ecologyandsociety.org/vol17/iss1/art10/ responses/

\section{Acknowledgments:}

We extend our gratitude to the tribal councils of Noatak and Selawik who supported the development of this project and granted us permission to conduct the research. We also want to thank all of our informants who took the time to share their insights and experiences. We are especially indebted to: Roger and Karen Mitchell, Thurston and Hilda Booth, Hannah Onalik, Rachel Sherman, Hannah Loon, Jack and Edith Snyder, Tanya Ballot, Clyde Ramoth, and Norma Ballot for their invaluable services provided during our visits to Noatak and Selawik. This project was developed and implemented in collaboration with Andres Lopez and Ellen Lopez. Our research has benefited from early advice from James Magdanz and Susan Georgette, and continuing collaboration with Caroline Brown, David B. Anderson, and Brittany Retherford. This work was funded by the U.S. Fish and Wildlife Service, Office of Subsistence Management, Project Number 10-152, and supported by Research Work Order number G10AC00473 from the United States Geological Survey and the Alaska Cooperative Fish and Wildlife Research Unit. Funding was also provided by the U.S. National Park Service, George Wright Melendenz Climate Change Fellowship, and the Alaska NSF EPSCoR Program. The contents of this article were composed solely by the authors and do not necessarily represent the official views of any of our funding sources. We thank Phillip Loring and two anonymous reviewers for their helpful comments, which have improved this paper. We alone are responsible for any errors or misrepresentations contained within this publication.

\section{LITERATURE CITED}

Arctic Climate Impact Assessment (ACIA). 2005. Arctic climate impacts assessment. Cambridge University Press, Cambridge, UK.

Berkes, F. 2008. Sacred ecology. Routledge, New York, New York, USA.

Berkes, F., J. Colding, and C. Folke. 2000. Rediscovery of traditional ecological knowledge as adaptive management. Ecological Applications 10:1251-1262. http://dx.doi.org/10.1 890/1051-0761(2000)010[1251:ROTEKA]2.0.CO;2

Berkes, F., and D. Jolly. 2001. Adapting to climate change: social-ecological resilience in a Canadian western Arctic community. Conservation Ecology 5(2): 18. [online] URL:

http://www.consecol.org/vol5/iss2/art18

Bernard, R. 2002. Research methods in anthropology: qualitative and quantitative approaches. AltaMira, Walnut Creek, California, USA.

Bersamin, A., B. Luick, C. Lardon, C. Wolsko, B. B. Boyer, J. S. Stern, and S. Zidenberg-Cherr. 2006. Some consequences of the delocalization of the food system in rural Alaska Native communities: the CANHR Study. Faseb Journal 20:A552A553.

Buklis, L. S. 1999. A description of economic changes in commercial salmon fisheries in a region of mixed subsistence and market economies. Arctic 52:40-48.

Burch, E. S. 2006. Social life in northwest Alaska: the structure of Iñupiaq Eskimo Nations. University of Alaska Press, Fairbanks, Alaska, USA.

Case, D. S., and D. A. Voluck. 2002. Alaska natives and American laws. University of Alaska Press, Fairbanks, Alaska, USA.

Chance, N. A. 1990. The Iñupiat and Arctic Alaska: an ethnography of development. Holt, Rinehart and Winston, Fort Worth, Texas, USA.

Condon, R. G., P. Collings, and G. Wenzel. 1995. The best part of life- subsistence hunting, ethnicity, and economic adaptation among young-adult Inuit males. Arctic 48:31-46.

Corell, R. W. 2006. Challenges of climate change: an Arctic perspective. Ambio 35:148-152. http://dx.doi.org/10.1579/00 44-7447(2006)35[148:COCCAA]2.0.CO;2 
Crosby, B. T. 2009. Progressive growth, modulated supply: how coupling and decoupling between an enormous retrogressive thaw slump and its depositional fan impacts sediment delivery to the Selawik River, Northwest Alaska. Eos Transactions, American Geophysical Union, Fall Meeting Supplement 90:Abstract U41C-0043.

Cruikshank, J. 2001. Glaciers and climate change: perspectives from oral tradition. Arctic 54:377-393.

Dowsley, M. 2009. Community clusters in wildlife and environmental management: using TEK and community involvement to improve co-management in an era of rapid environmental change. Polar Research 28:43-59. http://dx.do i.org/10.1111/j.1751-8369.2008.00093.x

Drucker, J. H. 1996. Out of harm's way: relocating Northwest Alaska Eskimos, 1907-1917. American Indian Culture and Research 20:43-71.

Duerden, F. 2004. Translating climate change impacts at the community level. Arctic 57:204-212.

Forbes, B. C., F. Stammler, T. Kumpula, N. Meschtyb, A. Pajunen, and E. Kaarlejarvi. 2009. High resilience in the Yamal-Nenets social-ecological system, West Siberian Arctic, Russia. Proceedings of the National Academy of Sciences of the United States of America 106:22041-22048. http://dx.doi.org/10.1073/pnas.0908286106

Ford, J. D. 2009. Vulnerability of Inuit food systems to food insecurity as a consequence of climate change: a case study from Igloolik, Nunavut. Regional Environmental Change 9:83-100. http://dx.doi.org/10.1007/s10113-008-0060-x

Ford, J. D., and C. Furgal. 2009. Foreward to the special issue: climate change impacts, adaptations and vulnerability in the Arctic. Polar Research 28:1-9. http://dx.doi.org/10.1111/j.17 51-8369.2009.00103.x

Ford, J. D., and B. Smit. 2004. A framework for assessing the vulnerability of communities in the Canadian Arctic to risks associated with climate change. Arctic 57:389-400.

Ford, J. D., B. Smit, and J. Wandel. 2006. Vulnerability to climate change in the Arctic: a case study from Arctic Bay, Canada. Global Environmental Change 16:145-160. http://dx. doi.org/10.1016/j.gloenvcha.2005.11.007

Ford, J. D., B. Smit, J. Wandel, M. Allurut, K. Shappa, H. Ittusarjuat, and K. Qrunnut. 2008. Climate change in the Arctic: current and future vulnerability in two Inuit communities in Canada. Geographical Journal 174:45-62. http://dx.doi.org/10.1111/j.1475-4959.2007.00249.x

Fox, S. 2002. These are things that are really happening: Inuit perspectives on the evidence of climate change in Nunavut. Pages 13-53 in I. Krupnik and D. Jolly, editors. The earth is faster now: indigenous observations of Arctic environmental change. Arctic Research Consortium of the United States, Fairbanks, Alaska, USA.
Gearheard, S., W. Matumeak, I. Angutikjuaq, J. Maslanik, H. P. Huntington, J. Leavitt, D. M. Kagak, G. Tigullaraq, and R. G. Barry. 2006. "It's not that simple": a collaborative comparison of sea ice environments, their uses, observed changes, and adaptations in Barrow, Alaska, USA, and Clyde River, Nunavut, Canada. Ambio 35:203-211. http://dx.doi.org /10.1579/0044-7447(2006)35[203:INTSAC]2.0.CO;2

Hall, E. S., Jr. 1971. The "iron dog" in Northern Alaska. Anthropologica 13:237-254. http://dx.doi.org/10.2307/25604852

Hinzman, L. D., N. D. Bettez, W. R. Bolton, F. S. Chapin, M. B. Dyurgerov, C. L. Fastie, B. Griffith, R. D. Hollister, A. Hope, H. P. Huntington, A. M. Jensen, G. J. Jia, T. Jorgenson, D. L. Kane, D. R. Klein, G. Kofinas, A. H. Lynch, A. H. Lloyd, A. D. McGuire, F. E. Nelson, W. C. Oechel, T. E. Osterkamp, C. H. Racine, V. E. Romanovsky, R. S. Stone, D. A. Stow, M. Sturm, C. E. Tweedie, G. L. Vourlitis, M. D. Walker, D. A. Walker, P. J. Webber, J. M. Welker, K. S. Winker, and K. Yoshikawa. 2005. Evidence and implications of recent climate change in northern Alaska and other Arctic regions. Climatic Change 72:251-298. http://dx.doi.org/10.1007/s10584-005-5352-2

Huntington, H. 1998. Observations on the utility of the semidirective interview for documenting traditional ecological knowledge. Arctic 51:237-242.

Huntington, H. P., L. C. Hamilton, C. Nicolson, R. Brunner, A. Lynch, A. E. J. Ogilvie, and A. Voinov. 2007. Toward understanding the human dimensions of the rapidly changing Arctic system: insights and approaches from five HARC projects. Regional Environmental Change 7:173-186. http://d x.doi.org/10.1007/s10113-007-0038-0

Jorgensen, D. L. 1989. Participant observation: a methodology for human studies. Sage, Thousand Oaks, California, USA.

Krupnik, I., and D. Jolly, editors. 2002. The earth is faster now: indigenous observations of Arctic environmental change. Arctic Research Consortium of the United States, Fairbanks, Alaska, USA.

Kuhnlein, H. V., O. Receveur, R. Soueida, and G. M. Egeland. 2004. Arctic Indigenous Peoples experience the nutrition transition with changing dietary patterns and obesity. Journal of Nutrition 134:1447-1453.

Loring, P. A., and S. C. Gerlach. 2009. Food, culture, and human health in Alaska: an integrative health approach to food security. Environmental Science \& Policy 12:466-478. http:// dx.doi.org/10.1016/j.envsci.2008.10.006

Lynch, A. H., and R. D. Brunner. 2007. Context and climate change: an integrated assessment for Barrow, Alaska. Climatic Change 82:93-111. http://dx.doi.org/10.1007/s10584-006-9165-8 
Magdanz, J., N. Braem, B. C. Robbins, and D. S. Koster. 2010. Subsistence harvests in Northwest Alaska, Kivalina and Noatak, 2007. Department of Fish and Game Technical Paper No. 354, Kotzebue, Alaska, USA.

Moller, H., F. Berkes, P. O. Lyver, and M. Kislalioglu. 2004. Combining science and traditional ecological knowledge: monitoring populations for co-management. Ecology and Society 9(3): 2. [online] URL: http://www.ecologyandsociety. org/vol9/iss3/art2

Napoleon, H. 1996. Yuuyaraq: the way of the human being. Alaska Native Knowledge Network, Fairbanks, Alaska, USA.

Nichols, T., F. Berkes, D. Jolly, N. B. Snow, and the Community of Sachs Harbor. 2004. Climate change and sea ice: local observations from the Canadian Western Arctic. Arctic 57:68-79.

O'Brien, K. L., and R. M. Leichenko. 2000. Double exposure: assessing the impacts of climate change within the context of economic globalization. Global Environmental Change 10:221-232. http://dx.doi.org/10.1016/S0959-3780(00)00021-2

Oozeva, C., C. Noongwook, G. Noongwook, C. Alowa, and I. Krupnik. 2004. Watching ice and weather our way. Arctic Studies Center, Smithsonian Institution, Washington, D.C., USA.

Riedlinger, D., and F. Berkes. 2001. Contributions of traditional knowledge to understanding climate change in the Canadian Arctic. Polar Record 37:315-328. http://dx.doi.org/ 10.1017/S0032247400017058

Turner, B. L., II, P. A. Matson, J. J. McCarthy, R. W. Corell, L. Christensen, N. Eckley, G. K. Hovelsrud-Broda, J. X. Kasperson, R. E. Kasperson, A. Luers, M. L. Martello, S. Mathiesen, R. Naylor, C. Polsky, A. Pulsipher, A. Schiller, H. Selin, and N. Tyler. 2003. Illustrating the coupled humanenvironment system for vulnerability analysis: three case studies. Proceedings of the National Academy of Sciences of the United States of America 100:8080-8085. http://dx.doi.or g/10.1073/pnas. 1231334100

Tyler, N. J. C., J. M. Turi, M. A. Sundset, K. Strøm Bull, M. N. Sara, E. Reinert, N. Oskal, C. Nellemann, J. J. McCarthy, S. D. Mathiesen, M. L. Martello, O. H. Magga, G. K. Hovelsrud, I. Hanssen-Bauer, N. I. Eira, I. M. G. Eira, and R. W. Corell. 2007. Saami reindeer pastoralism under climate change: applying a generalized framework for vulnerability studies to a sub-arctic social-ecological system. Global Environmental Change 17:191-206. http://dx.doi.org/10.1016/ j.gloenvcha.2006.06.001

United States Census Bureau. 2010. American fact finder. U. S. Census Bureau, Washington, D.C., USA. [online] URL: http://factfinder2.census.gov/faces/nav/jsf/pages/index.xhtml
West, J., and G. K. Hovelsrud. 2010. Cross-scale adaptation challenges in the coastal fisheries: findings from Lebesby, Northern Norway. Arctic 63:338-354.

Wolfe, R. J., and L. J. Ellanna. 1983. Resource use and socioeconomic systems: case studies of fishing and hunting in Alaskan communities. Alaska Department of Fish and Game, Technical Paper No. 61, Juneau, Alaska, USA.

Wolfe, R. J., and R. J. Walker. 1987. Subsistence economies in Alaska: productivity, geography, and development impacts. Arctic Anthropology 24:56-81.

Wolsko, C., C. Lardon, S. Hopkins, and E. Ruppert. 2006. Conceptions of wellness among the Yup'ik of the YukonKuskokwim Delta: the vitality of social and natural connection. Ethnicity \& Health 11:345-363. http://dx.doi.org $\underline{110.1080 / 13557850600824005}$

Wolsko, C., C. Lardon, G. V. Mohatt, and E. Orr. 2007. Stress, coping, and well-being among the Yup'ik of the YukonKuskokwim Delta: the role of enculturation and acculturation. International Journal of Circumpolar Health 66:51-61. 